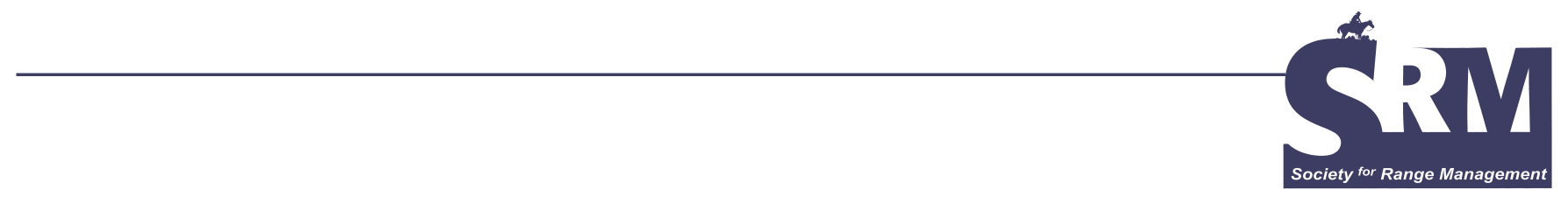

\title{
Career Opportunities in Rangeland Ecology
}

\section{By Wayne C. Leininger and Melissa Johnson}

I mportant questions that are being asked at this time of the year by students entering college include: Will there be any jobs when I graduate with my bachelor's degree in rangeland ecology/management? Who employs range graduates? What do graduates with a range degree do anyway? If these questions are not asked by the students, most likely their parents ask them. This article gives some insight into these important questions and others.

\section{Changing Career Opportunities}

Careers for graduates with bachelor degrees in rangeland ecology/management have changed dramatically since the first students with these degrees graduated in the early 1900s. During this time, livestock grazing issues (eg, lowered grazing capacity, increased soil erosion, etc) on both public and private lands were of great concern. Range careers typically involved working for a federal land-management agency, such as the Forest Service, monitoring livestock numbers, enforcing grazing regulations, and installing range structures (fences, water developments, etc). Over the next several decades, rangeland conservationists shifted more of their responsibilities toward improving the rangeland resource that had been subjected to land abuse from overgrazing and drought. Rangeland specialists developed grazing systems, implemented rangeland improvements, such as reseedings and brush control, and evaluated and monitored rangeland condition.

The 1960s and 1970s were characterized by considerable change in the philosophy of range management. With the passage of several legislative acts (eg, Multiple Use Act [1960], National Environmental Policy Act [1969], Federal Lands Policy and Management Act [1976]), the focus of range management on public lands changed from only livestock grazing toward multiple uses, such as grazing, recreation, wildlife habitat, watershed management, etc. ${ }^{1}$ During this era, student numbers in range programs in the United States increased considerably and employment opportunities for graduates with a range degree were plentiful.

The 1980s and 1990s saw changes in national priorities, budget deficits, and subsequent reductions in federal work forces within many governmental agencies. This was also a time when graduates with range degrees often looked toward the private sector and nongovernmental organizations (NGOs), such as the Nature Conservancy, for employment. It was also an era when undergraduate enrollment in natural resource programs declined dramatically. ${ }^{2}$

\section{A Bright Future}

Career opportunities for graduates with range degrees in the 2000s appear very bright. Much of this has to do with the impending wave of retirements in all environmental and natural resource agencies and the concern by agencies relative to loss of institutional memory and maintaining their managerial competencies. ${ }^{2}$ For example, over $40 \%$ of the government workforce is over the age of 50, approximately $23 \%$ have more than 25 years of service, and only $6 \%$ are under the age of 30 . The workforce in the natural resource agencies mirrors these statistics with the length of service slightly longer. 


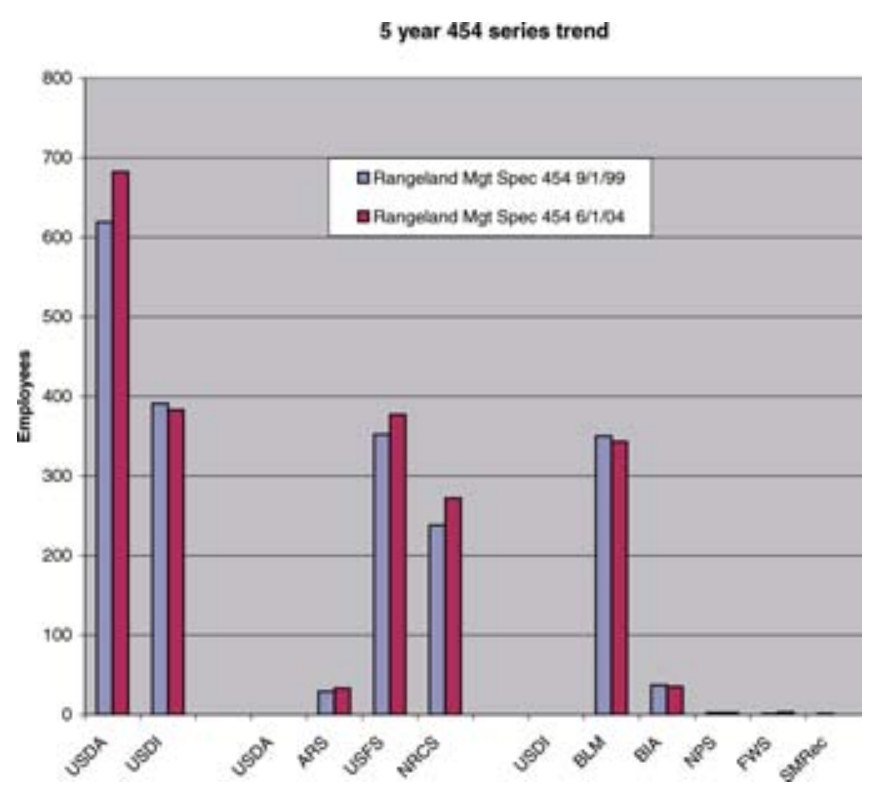

Figure 1. Numbers of rangeland management specialists in the various land management agencies September 1, 1999, compared with June 1, 2004. Note that SMRec = surface-mining and reclamation.

Forty-six percent of the Forest Service's permanent workforce is projected to turn over between 2003 and 2007. ${ }^{2}$ Similarly, the Natural Resources Conservation Service projects that it will potentially lose one-third to one-half of their employees over the next 5-10 years. In Colorado, there are 40 range-trained employees, and $40 \%$ of them are eligible to retire in the next 5 years (L. Jolley, personal communication, 2005). As noted in Figures 1 and 2, the number of range employees within the federal agencies increased between

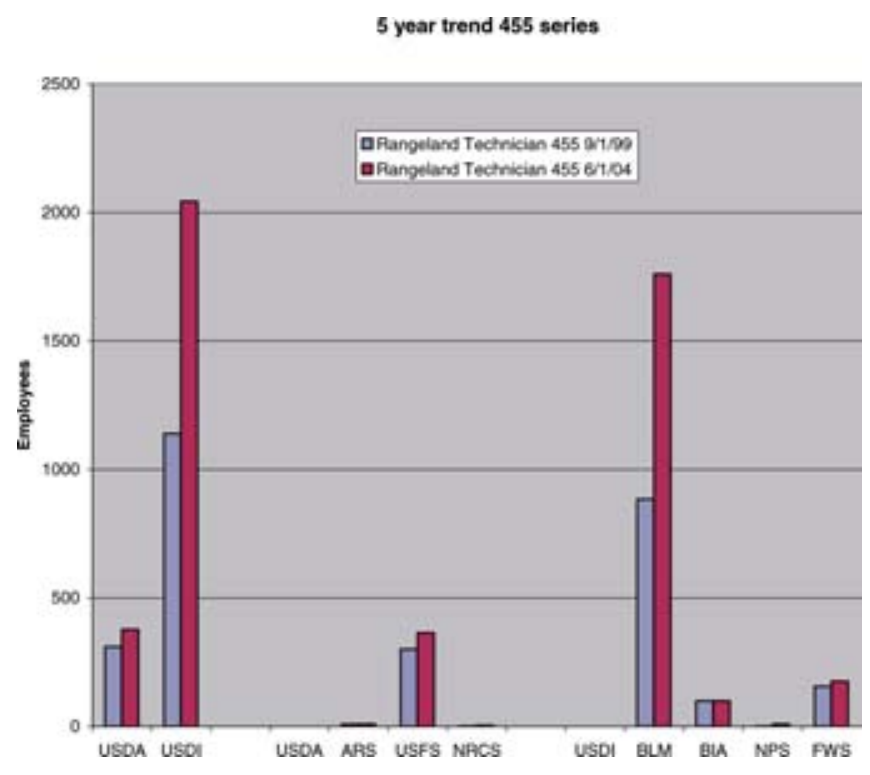

Figure 2. Number of rangeland technicians in the various land management agencies September 1, 1999, compared with June 1, 2004.
1999 and 2004 (see www.fedscope.opm.gov for data on employee numbers). Hopefully, this is the start of a new wave of hiring not seen since the 1970s.

Placement of students with range degrees has been very good. Summer positions generally outnumber the available range students and many summer range positions are filled with students in a closely aligned discipline, such as natural resources management. At Colorado State University, the placement of rangeland ecology undergraduates has been the highest of the eight majors in the College of Natural Resources (Table 1).

\section{What Do Graduates With a Range Degree Do?}

Graduates with a bachelor of science degree in rangeland ecology/management have a wide variety of employment opportunities. Many choose to work for the federal agencies

Table 1. Job placement at the time of graduation for College of Natural Resources Undergraduates, 1999-2004. Percentages include students employed or attending graduate school

\begin{tabular}{|l|c|}
\hline Major & Percentage \\
\hline Fishery biology & 62 \\
\hline Forestry & 61 \\
\hline Geology & 48 \\
\hline Natural resources management & 52 \\
\hline $\begin{array}{l}\text { Natural resources recreation } \\
\text { and tourism }\end{array}$ & 66 \\
\hline Rangeland ecology & 75 \\
\hline Watershed science & 57 \\
\hline Wildlife biology & 59 \\
\hline
\end{tabular}

as rangeland-management specialists. Generally, these individuals are involved in monitoring rangeland condition/health, monitoring and controlling invasive plants, developing allotment management plans, implementing habitat improvements, placing natural processes, such as fire, into the ecosystem, etc. A high percentage of the undergraduates with a range degree in the new millennium seek employment with NGOs. Much of their time is directed toward managing rangelands to enhance biodiversity, seeking ways to preserve open space, etc. Ranches frequently hire graduates from range programs to be ranch managers. These individuals are responsible for the day-to-day operation of the ranch, including stewardship of the animal and rangeland resources.

Colorado State has placed a considerable number of range-trained graduates with city and county open-space programs. Typically, these employees are charged with balancing 


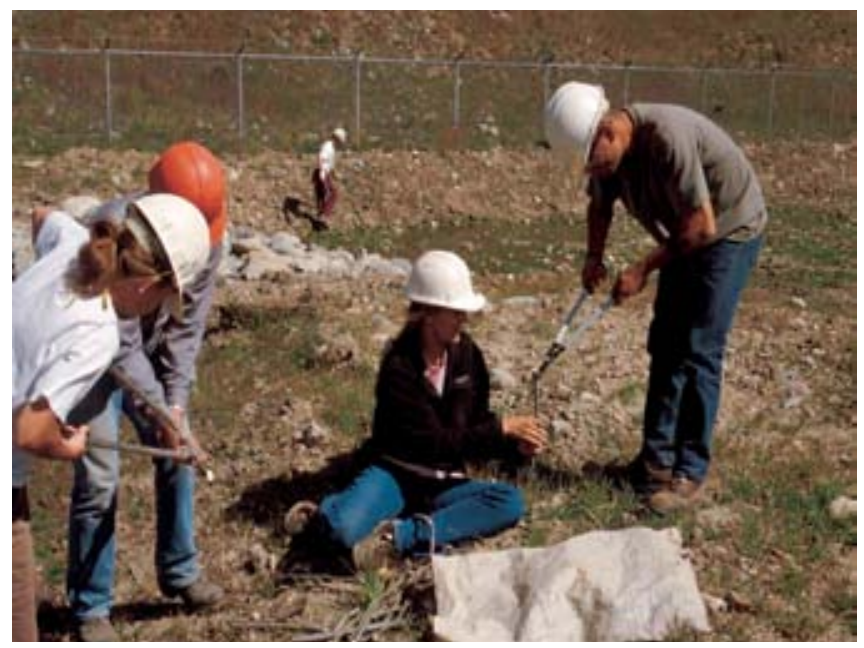

Figure 3. Restoration ecologists cutting willows for a riparian restoration project.

recreational demands with ecosystem sustainability. In some cases, open-space managers focus their attention on maintaining traditional uses of rangelands, such as livestock grazing. Over the past 20 years, private industry, such as mining companies, have employed a large number of graduates in range management to help in the restoration of drastically disturbed sites. These challenging positions involve the integration of biology, soils, and economics in developing costeffective ways to put natural plants and ecosystem processes into a restored site. Environmental consulting companies have always been a major employer of range-trained graduates. Employees of these companies typically work in diverse areas such as wetland delineation and mitigation, threatened and endangered plant and animal surveys, etc.

\section{Summary}

Employment opportunities for range graduates look very promising in the coming decade. This is largely brought about by the retirement of a large body of graduates who were hired during the environmental movement of the 1970s. Graduates in range management generally find their career to be very rewarding and appreciate the diversity of opportunities a range degree offers. Many students who pursue a range degree want to work in the outdoors. Presently, a growing number of stu-

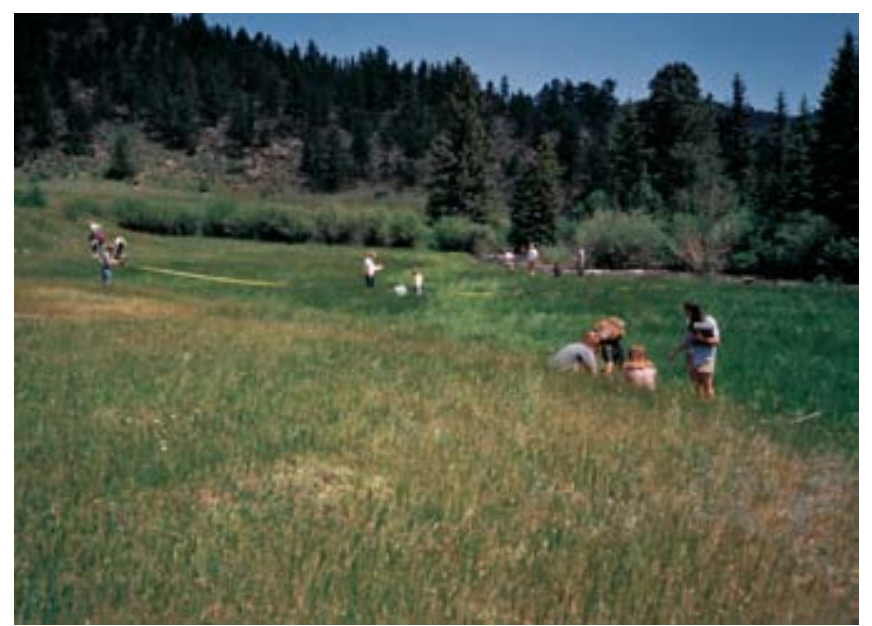

Figure 4. Riparian specialists assessing the ecological health of a riparian zone.

dents are taking the opportunity to integrate resource-management skills with technological tools, such as geographical information systems and remote sensing. The unknown factor in employment opportunities, however, is the growing federal deficit and its effect on the ability of federal agencies to fill vacancies. Only time will tell how this plays out.

\section{References}

1. Holecheck, J. L., R. D. Pieper, and C. H. Herbel. 2004. Range management principles and practices. 5th ed. Upper Saddle River, NJ: Pearson Prentice Hall.

2. Renewable Natural Resources Foundation. 2003/2004. Federal natural resource agencies confront an aging workforce and challenges to their future roles. Renewwable Resources Journal 21(4):1-31.

Authors are Professor, Forest, Rangeland, and Watershed Stewardship Department (Wayne C. Leininger), and Assistant Director, Career Center (Melissa Johnson), Colorado State University, Fort Collins, CO 80523. The authors would like to acknowledge Leonard Jolley, who supplied much of the data on federal employment for this paper. 